\title{
SLEEVEBANDS: NEGLECTED ELEMENT IN CHINESE ADORNMENT
}

\author{
Helena Heroldová ${ }^{1}$
}

\begin{abstract}
Embroidered bands on the edges of the sleeves of women's garments were fashionable in China during the late $19^{\text {th }}$ century. They adorned Manchu and Han ladies' garments with colourful landscapes, flowers and birds, figural scenes and auspicious symbols that expressed wishes for long life, many male offspring, and an advance in social position.
\end{abstract}

KEYWORDS: adornment - dress - embroidery - Qing dynasty - China

Colourful bands of fabrics embroidered with landscapes, flowers, birds, insects, auspicious symbols, and human figures decorated the large sleeves of women's garments in China during the second half of the $19^{\text {th }}$ century. Many museums keep collections of the sleevebands, and the Náprstek Museum has acquired 177 pieces. Textile history researchers mention sleevebands in almost every book concerning the history of the Qing dynasty (1644-1911) clothing. However, detailed analyses are not so frequent, and sleevebands were even described as neglected elements in the studies concerning clothing in China. ${ }^{2}$ Verity Wilson has devoted a chapter to sleevebands and garment edgings in her study Chinese Dress, which was based upon the collections in the Victoria and Albert Museum in London, ${ }^{3}$ and the edgings of garments were depicted in Valery Garrett's study about clothing in China from the Qing dynasty until now. ${ }^{4}$ This present study follows the work Between Cultures, ${ }^{5}$ which focused on the collection of the late Qing dynasty clothing of Manchu and Han ethnic groups in the Náprstek Museum; sleevebands, however, were only briefly mentioned there. Therefore, this study continues in more detail in the analyses of the composition and symbolism of sleevebands in their cultural and aesthetic contexts.

\section{Garments from China in the Náprstek Museum}

The Náprstek Museum keeps a collection of several hundred garments and dress accessories from the late Qing dynasty China, namely from the last decades of the $19^{\text {th }}$ cen-

1 Contact: Helena Heroldová, National Museum - Náprstek Museum of Asian, African and American Cultures, Prague, Czech Republic; e-mail: helena.heroldova@nm.cz. This work was financially supported by Ministry of Culture of the Czech Republic (DKRVO 2019-2023/19.I.b, National Museum, 00023272).

2 Haig and Shelton 2006, p. 131.

3 Wilson 1986, pp. 61-65.

4 Garrett 2020, p. 79

5 Heroldová 2017.

This work is licensed under the Creative Commons Attribution-Noncommercial-No Devivs 3.0 License 
tury and the beginning of the $20^{\text {th }}$ century. Approximately forty dragon robes represent men's semi-official style of dressing, and the same number counts for women's skirts, vests, gowns, and jackets. Among the accessories, purses, fan cases, men's hats, and men's and women's shoes form a large part of the collection. Although the collection is not small in number, information about its provenance is rather scarce. The earliest objects were acquired after Vojta Náprstek (1826-1894) opened his museum in 1874. By the end of the $19^{\text {th }}$ century, 238 items from China were recorded in the Museum acquisition ledgers. The earliest acquisitions, such as curios, porcelain, and a few pieces of Chinese dress suggested that they were purchased from retailers either in Prague or other places around Europe and given as gifts to the Museum. However, only a few names of donors are known today from the museum inventory books until the end of the $19^{\text {th }}$ century. ${ }^{6}$ During the first decades of the $20^{\text {th }}$ century, the enthusiastic amateurs - artists and literati - built extensive collections of Chinese objects from purchases in the antiquities and curios market in Europe. The museum purchased their collections decades later, mostly during the 1960s. They collected art mainly, however, Rưžena Trnožková (1868-1936) focused on collecting Chinese and Japanese textiles. The 1950s and 1960s was also the period when most of the objects came to the museum when the state authorities distributed the confiscated properties of former aristocratic and German families after World War II. Unfortunately, the original provenance of those collections is unknown.

Although the provenance of the collection of textiles for the most part remains unknown, an important primary source for the study of late Qing dress is available. The Náprstek Museum holds the collection of photographs made by Enrique Stanko Vráz (1860-1932), a traveller and photographer during the formative years of the Náprstek Museum. Vráz travelled extensively around the world, photographed, wrote travelogues, and collected items. He visited China twice. For the first time, he stopped there shortly in 1896 during his travels to Borneo and New Guinea. For the second time, he purposefully travelled to China as his destination. In 1901 he decided to photograph the so-called Boxer Uprising, the nationalist and anti-foreigners upheaval in Northern China. ${ }^{7}$ As opposed to other travellers associated with the Náprstek Museum who sometimes took pictures, E. S. Vráz was the photographer who took photographing seriously. During his three-months sojourn in Beijing, he made several hundreds of pictures, including landscapes, street scenes, ${ }^{8}$ the Forbidden City abandoned by the Imperial Court, and the estates of Manchu aristocracy. Vráz's contemporaries knew him as a congenial person who made friends from various walks of life. His friendly nature helped him to take pictures not only of leading political figures of the day but also of their wives and children. His photographs of Manchu ladies in their beautiful gowns and elaborated hair and dress walking in gardens and sitting in courtyards of wealthy houses represented a vital source for comparison with the Manchu and Han Chinese garments kept in the Náprstek Museum.

6 Heroldová 2011, p. 51.

7 Vráz also purchased and recieved a few objects during his stay in China. However, his small travel budget limited him in his purchases (see No. 8).

8 It was only two decades since the photographs of people on the streets of Chinese cities appeared. The photographers made studio photos in the 1860s, and the earliest identified photographs from China dated to 1844-1845. Bertholet and van der Aalsvoort 2014, p. 15. 


\section{Late Qing Women's Garments and its Sleeves}

Qing dynasty dress, its accessories and adornment for men and women were divided into categories according to their social function from the formal garments worn at the court during the state rituals to semi-formal robes worn by the courtiers and government officials to informal robes serving as every-day attire. Different dress codes were described in the essential text dealing with the Qing dynasty garments: The Illustrated Regulations for Ceremonial Paraphernalia of the Imperial Court (Huangchao ligi tushi 皇朝礼 器图式), published in 1766. These rules applied equally to the ruling Manchus and the Manchu and Chinese government officials who served in the Qing dynasty administration. ${ }^{9}$ However, as for the category of informal garments, there were different types of clothes for women of Manchu and Han ethnicity. A critical difference is that Manchu women wore long gowns, while Han women wore jackets, skirts, and pants.

The Manchu gowns kept in the Náprstek Museum show the usual cut: an anklelength, long, slim A-shaped body mostly with long narrow sleeves; however, full sleeves were also used. The formal and semi-formal gowns had sleeves with embroidered horseshoe-shaped cuffs - the typical element of men's and women's Manchu garment. The Han Chinese jackets are short, reach below the hips or above the knees, with an opening in the front or on one side. The sleeves are wide. The construction of the sleeves for a Manchu gown and Han Chinese jacket sleeves is the same: one long piece of the sleeve extends from the bodice, forming a T-like shape. In Western dress construction, this type is called a 'kimono sleeve', according to the Japanese dress for which this construction is generally known in the West. Unlike kimono sleeves, Western dress construction sleeves are cut separately from the bodice and attached to the garment by a sleeve head that is curved to adjust to the shape of the shoulder. The resulting narrow sleeves fit snuggly around the arms. Unlike the narrow sleeves with a head, the kimono sleeves tend to rotate inward towards the front of the body. To be comfortable to wear a kimono style gown, the sleeves must be large with a wide armscye. Large sweeping sleeves appear regularly in Chinese clothing history. During the Qing dynasty, the painting genre 'beautiful ladies' showed the beauties wearing large sleeves that swirled around their arms. ${ }^{10}$ Full sleeves with straight edges of Han and Manchu garments represented the place for intricate embellishment. Jacquard woven ribbons and embroidered bands decorated the edges of the sleeves, while silk fabrics of contrasting colours inside the full sleeves made a visual effect when turned back. Sleeveband were attached either to the outside of the sleeve or the inside. The inside sleevebands were visible when the sleeve was turned out and up.

No. 1

Manchu ladies

Glass plate negative

Dimensions: $20 \times 12.5 \mathrm{~cm}$

9 The Manchus established the Qing dynasty (1644-1911). The Manchus belong to Tungusic peoples. They came from modern-day Manchuria in China's Northeast, while Han Chinese is the native nation to China. The Manchus conquered China and established the multiethnic and multicultural empire with Chinese territory as its most important part.

10 Multiple layers of opened sleeves pulled back to show the forearm expressed sexual allusion, and extremely wide sleeves appeared also on photographs of courtesans from the 1860s. Cahill 2010, pp. 154157; Cahill 2013, pp. 88, 110; Yeh 2006, pp. 55-57. 
E. St. Vráz (1860-1932), 1901

Inv. No. As I $7036 \mathrm{ab}$

A young lady from an upper-class family is wearing the Manchu style gown with several bands in contrasting colours around the edges of her long gown. The same combination of bands adorns the sleeves at the elbow. It seems that the embroidery of wisteria flowers embellishes the dark-coloured band. At least three layers of sleeves are visible. Vráz visited China between January and April, and those months are cold in Beijing. In winter, women wore several layers of garments for protection against the cold weather. The lady behind the young one is wearing a jacket over her long gown. Layers of sleeves are also visible.

No. 2

Manchu newlyweds

Glass plate negative

Dimensions: $18 \times 13 \mathrm{~cm}$

E. St. Vráz (1860-1932), 1901

Inv. No. As I $83 \mathrm{ab}$

A newly married couple (according to Vráz's description on the negative) are on the veranda of their house. The house and the dress show the lesser status of the family as compared to photo above (No. 1). The young lady is wearing a padded gown with a dark border and a narrow, woven band. The other woman is wearing a simple cotton gown with dark borders.

\section{No. 3}

Manchu gown

Kesi weaving with additional painting

Length: $135 \mathrm{~cm}$

Acquisition: Růžena Trnožková (1868-1936) ${ }^{11}$

Late $19^{\text {th }}$ century, early $20^{\text {th }}$ century

Inv. No. A/4799

Here is a Manchu style ${ }^{12}$ gown, informal style, in violet colour with black borders with blue clouds, cranes, and bats, a Jacquard ${ }^{13}$ ribbon, with off-white bands embroidered with butterflies and orchids. The fabric of the gown is made using the kesi 缂丝 ('carved silk'), a silk tapestry weaving technology. Kesi originated in Central Asia and has been made in China since the $10^{\text {th }}$ century. The skilled artisans produced intricate designs of flowers, animals, and human figures on fabric. During the Qing dynasty, paintings highlighted details, ${ }^{14}$ such was this example, where the shading of flowers was painted. Butterflies were a popular motif for women's garments in the $19^{\text {th }}$ century; among their many symbolic meanings they symbolised summer, dreams, and love as well as blessing. ${ }^{15}$

11 Růžena Trnožková acquired a large collection of textiles from China and Japan, now in the Náprstek Museum.

12 For comparison with a Han Chinese jacket, see No. 5. The Han Chinese jacket is shorter and larger.

13 Jacquard: a system of weaving that utilises a highly versatile pattern mechanism to permit the production of large, intricate designs. Complete Textile Glossary 2001.

14 Heroldová 2013.

15 Welch 2008, pp. 91-92. 


\section{The Aesthetic of Contrasting Colours}

The Manchu style gowns and Han Chinese jackets from the Náprstek Museum show attached bands in contrasting colours around the edges of the garment; lightcoloured bands adorned the dark-coloured fabric, and pale-coloured garments sported dark colours. Photographs ${ }^{16}$ and copperplate engraving for a newspaper illustration ${ }^{17}$ from the $19^{\text {th }}$ century document the look of garments with contrasting borders. Bands of contrasting colours were fashionable even to the thirties of the $20^{\text {th }}$ century. The advertisement for consumer goods from the $1920 \mathrm{~s}$ and $1930 \mathrm{~s}$ showed alluring women in close-fitting gowns with contrasting edgings; those lines seemed to emphasise their body shape even more than the garment itself. Social ladies and actresses were photographed in the latest fashion Chinese style dress with contrasting borders. ${ }^{18}$

Borders in contrasting colours were used throughout the history of dress in China. ${ }^{19}$ According to archaeological finds of clay and wooden tomb figurines as well as of clothes, contrasting edgings appeared early in the history of dress in China. The earliest bands were probably painted, later they were embroidered and woven with patterns. The embroideries of clouds and fantastic animals were produced earlier than woven bands with geometric patterns because the round shapes were easy to embroider but difficult to weave until weaving technology improved. After weaving technologies advanced, woven bands were commonly used. ${ }^{20}$ The embroidered and woven bands had a practical function because the additional layer of fabric on the edges of the garment made the sleeve ends stiffer and more resistant to damage caused by wearing.

Contrasting bands were described in the classic work $\mathrm{Li}$ Ji 禮記 (The Book of Rites), the collection of ritual texts written during the later Warring States $\left(5^{\text {th }}\right.$ century - 221 BCE) and Former Han (206 BCE - 8 CE). It is one of the Three Ritual Texts and Five Confucian Classics, and throughout the history of Imperial China, it was widely known among the educated class since every scholar aspiring to hold a position in the government administration of the Empire studied the texts. In the chapter called Shenyi 深衣 (The Deep Robe), the cut and appearance of the robe compared to the moral behaviour of a man. Even the attached band had a symbolic meaning:

Having one's parents and grandparents [alive] (具父母、大父母 ju fumu, da fumu), [their son] wears the robe with multicoloured bands (衣純以繢 yi chun yi hui); having the parents [alive] (具父母 ju fumu), the band is a dark colour (衣 純以青 yi chun yi qing); if [one] is an orphan (如孤子 ru guzi), the band is plain (衣純以素 yi chun yi su). [The bands around] the sleeves, edges and hems [of the robe] measure $4.5 \mathrm{~cm}$ (純袂、緣、純邊 , 廣各寸半 chunmei, yuan, chunbian, guang ge cun ban). ${ }^{21}$

16 Cody 2011, pp. 72-74, 77.

17 Yeh 2006, p. 49.

18 Fajcsák and Kelényi 2017, p. 40.

19 Zhou and Gao 1997, p. 297.

20 Kuhn 1995, p. 105.

21 Liu 1992, p. 547; English translation by the author. 


\section{Embroidery: Local Symbolism and Global Context}

Garments from the late Qing dynasty were lavishly adorned with embroideries that represented a complex symbolic system based on the Chinese language, mythology, literature, and customs. Although this intricate system of symbolism embraces the local uniqueness, embroidery perceived as 'a global phenomenon' 22 transcends the local view and brings a new understanding in the context of general symbolic thinking: the placement of embroideries on the human body expresses similar concepts around the world. Some parts of the body - breasts, the chest, shoulders, the stomach, and the genitals - needed physical as well as magical protection. The embroideries protected the fabric, and various symbols provided the magical protection. Embroideries on cuffs, around the neckline and at the bottom of the dress, were believed to prevent evil spirits from attempting to enter the human body. ${ }^{23} \mathrm{I}$ believe that in the global context the sleevebands belong to elements with a protective function, even though this knowledge was not perceived during the late Qing dynasty, and the embroidery had mainly an aesthetic function. ${ }^{24}$

No. 4

Woodblock print

Print, colours on paper

Dimensions: $54 \times 64 \mathrm{~cm}$

Acquisition: Antiquity books market, 1975

Late $19^{\text {th }}$ century

Inv. No. 46268

Coloured woodblock prints were used for New Year's household decorations and pictured auspicious symbols as well as represented pleasing scenes of domestic life. A child is bringing a chessboard game ( $q i$ 棋) which is a homophone for $q i$ 者, very old. It thus represented the wishes for long life. ${ }^{25}$ The chessboard and books (one of the women is holding them) are symbols of scholarly erudition and learning. Together with the painting scroll and the musical instrument that are pictured on a paired woodblock print (not illustrated here, but also in possession of the Náprstek Museum), they represent the Four Arts of the Scholar. ${ }^{26}$ Besides the traditional symbols for long life and family success, kerosine lamps evoked the evening time in a traditional yet modern household.

Two women are wearing jackets, skirts and a vest trimmed with white fur for the winter evening. Peaches - symbols of long life - and orchids and narcissus associated with the New Year and wishes for many children decorated the jacket of the lady sitting in the front. The women are Han Chinese, with tiny 'Golden lotuses' shoes on their bound feet. This custom was practised only among the Han Chinese.

22 Welters and Lillethun 2018.

23 Paine 2010, pp. 191-192.

24 Paine 2010, p. 192.

25 Welch 2008, p. 248.

During the Qing dynasty women were not merely uneducated and illiterate. Many women from the literati class were prolific and well-known authors, poetesses, and painters. Women composed embroidery manuals in a similar style and language as male authors wrote about painting and calligraphy. See Fong 2010; Zurndorfer 1999. 
No. 5

Han Chinese jacket

Silk, embroidery and Jacquard ribbons

Length: $110 \mathrm{~cm}$

Acquisition: Růžena Trnožková (1868-1936), 1937

Late $19^{\text {th }}$ to early $20^{\text {th }}$ century

Inv. No. A5569

Publication: Heroldová 2017, p. 56.

Here is a women's Han Chinese jacket in the informal style embroidered with flowers and butterflies. The jacket has a usual Han Chinese style cut; it is short and wide, with full sleeves. There are two Jacquard ribbons and a hand-embroidered band on the edges. Embroideries of birds and butterflies among waters, rocks, and flowers (lotuses, roses, pomegranates, and mushrooms of immortality) adorn the sleeves. Creamcoloured sleevebands and ribbons in pastel shades contrast with the dark purple colour of the jacket.

\section{Sleevebands}

Rows of Jacquard woven and embroidered bands adorned the edges of semi-formal and informal Manchu style and Han Chinese women's garments after the middle of the $19^{\text {th }}$ century. ${ }^{27}$ Although both Manchu and Han garments sported colourful bands, ${ }^{28}$ the sleevebands adorned mostly the Han Chinese jackets. The sleevebands covered either the entire circumference of the sleeve length or just about its one half or two thirds. The embroidery, covering only a part of the sleeveband, was made to be visible from the front view. The less visible part of the sleeveband was either without any embroidery or with only a single motif, such as a tiny flower. Two sleevebands for two sleeves were created in mirror-like pairs. Sometimes both parts of the pair were identical; sometimes they differed in detail or colour.

There were varieties of materials and techniques for the sleevebands. The most common material for embroidery was silk satin in white, ivory, and cream colour, but bright colours such as red, purple, or dark blue were also used. Patterned twill and gauze were also employed. The satin stitch, so-called Peking knots and gold-work were favoured; however other types of stitches also appeared, such as a net stitch over a satin stitch background, and Florentine stitch on gauze. Since there are so many sleevebands found in museums today, there is a possibility that they were produced as stitch samplers. ${ }^{29}$ It could be because women were taught to do embroidery. Although professional embroiderers produced their gowns and jackets, even ladies from the high social class could make their sleevebands, shoes, purses, and sachets. Embroidery was a highly sought skill and girls prepared their dowries to take into their future husband's family. This skill was also associated with required feminine virtues such as diligence, calm demea-

27 Crick 2004, p. 120; Garrett 2020, p. 79; Haig and Shelton 2006, pp. 136-137, 141-142, 145; Wilson 1986, p. 62. Usually there were three rows of bands made of brocade, Jacquard and embroidery. During the second half of the $19^{\text {th }}$ century, Nanjing factories produced over three hundred patters of Jacquard ribbons, and Jacquard ribbons from China were displayed in the Vienna world exhibition in 1873. 
nour, and patience. ${ }^{30}$ The examples from the Náprstek Museum testify to different skill levels from mastery to only a basic knowledge of needlework. The sleevebands could have been produced with the help of the prepared printed or painted patterns: some sleevebands kept in the Chinese collection in the West Bohemia Museum in Pilsen are almost identical with the sleevebands from the Náprstek Museum. ${ }^{31}$

The sleevebands came in various motifs which can be divided into groups according to their composition. The following examples are based upon the collection in the Náprstek Museum. The choice of these particular sleevebands in the article was made to show their compositions, symbolism as well as embroidery technique and materials. Moreover, some examples were selected to present the earliest acquisitions in the collection.

The sleevebands in the collection of the Náprstek Museum are not attached to the garment: they were acquired as original pieces. For the following description, the selected sleevebands were therefore compared to the sleevebands on Han Chinese informal garments in order to identify the individual pieces as representing the Han Chinese style.

\section{Landscapes}

The majority of sleevebands in the Náprstek Museum depicts landscapes. They show stylised waters, high mountains among the clouds, trees, rocks, flowers, cottages, and pagodas. Contemporary art photographs of unfolded sleevebands, such as the examples in this article, encourage the Western viewer to read the sleeveband vertically, the same as the Western audience usually reads Chinese paintings. However, the Western viewer does not see the sleevebands as the Chinese did: the sleevebands wrapped around the full sleeves of the jacket lay obliquely rather than vertically.

No. 6

One sleeveband from a pair

Silk satin, embroidery (not finished)

Length: $102 \mathrm{~cm}$

Acquisition: Rudolf Dvořák (1860-1920), ${ }^{32} 1961$

Late $19^{\text {th }}$ century

Inv. No. A/1953a

Here is a landscape with water, mountains with a sun disc, rocks, and willow trees. There are various architecture elements: a pavilion, a bridge, a garden fence, and a tower. ${ }^{33}$

30 Fong 2010, pp. 12-13.

31 Heroldová and Mleziva 2011, pp. 88-89.

32 Rudolf Dvořák originally studied Classical and Oriental Philology in Bohemia (Prague) and Germany (Leipzig and Munich). His academic interests encompassed numerous extinct and living languages of Asia, including Chinese. He was a prolific translator who introduced literature of ancient cultures to the Czech-language readers. From his collections, 154 items from China came to the Náprstek Museum in 1961.

33 See the informal blue robe with cream-coloured sleevebands with landscapes embroidery. Haig and Shelton 2006, p. 136. 


\section{Flower and Birds, Flower Vases, and Baskets}

Compositions with flowers, birds, and insects in a landscape, and flowers in vases and baskets are frequent in the Náprstek Museum collection. Embroideries of landscapes, flowers, birds, and insects shared the same composition and motifs with the literati paintings. ${ }^{34}$ The union between embroidery and painting has a long tradition in China. During the Tang dynasty (618-907), the embroidered banners portrayed figural scenes with Buddhist topics. Since the Song dynasty (960-1279) the embroiderers produced embroideries that imitated painted hanging scrolls. The artistry of embroidery cultivated during the Ming (1368-1644) and Qing dynasties. Several schools and styles of embroidery developed from high art to folk production, which regularly employed motifs and compositions borrowed from paintings. ${ }^{35}$

\section{No. 7}

'Flowers and Birds'

Painting on silk, hanging scroll

Lenght: $140 \mathrm{~cm}$

Attributed to Lu Zhi 陸治 (1496-1576)

Inv. No. A/4900

No. 8

A sleeveband

Silk satin, embroidery

Length: $106 \mathrm{~cm}$

Acquisition: Enrique Stanko Vráz (1860-1932), 1903

Late $19^{\text {th }}$ century

Inv. No. 2872

This composition shows water, rocks, flowering bushes, and bamboos. Colourful birds are sitting on the branches and butterflies are flying around. The birds resemble the pheasant due to two long and two short tail feathers. Pheasants were associated with the second civil rank, ${ }^{36}$ one of the nine ranks in the system of the government.

No. 9

A sleeveband

Silk satin, embroidery

Length: $77 \mathrm{~cm}$

Acquisition: Rudolf Dvořák (1860-1920), 1961

Late $19^{\text {th }}$ century

Inv. No. A/1961

The sleeveband was embroidered on red silk satin. This example was chosen for this article to show various embroidery techniques. The large peony in the centre of the composition is embroidered in a knot stitch (dazi 打子). It was a time-consuming technique,

34 Rawson 2006, p. 384.

35 Chung 2003, pp. 18-30.

36 Garrett 2020, p. 117. 
and embroideries with knot stitch were greatly valued. ${ }^{37}$ The motifs of flower vases are commonly used Chinese painting; moreover, they are also part of the intricate world of Chinese symbolism. On account of homophony of terms in the Chinese language, the vase (ping 瓶) is homophonous with the term 'peace' (ping 平). ${ }^{38}$ Vases held things and thus represented abundance, ${ }^{39}$ while various flowers expressed desirable qualities such as beauty, resilience, or elegance. The so-called mushroom of immortality (lingzhi 靈 芝, Polyporus lucidus) was a frequent symbol of long life, and the 'wish-granting' sceptre (ruyi 如意) represented the precious object with the meaning of abundance and all wishes coming true. ${ }^{40}$

\section{Auspicious Symbols}

Auspicious symbols appeared in figural scenes where they were hidden among the decoration or in compositions formed solely from them. The language of auspicious symbols is rather complex, including flowers, plants, seeds, real and imaginary animals, objects, deities, numbers, as well as abstract motifs. Their meaning represented wishes for long life, a large family, many generations of offspring, and a high social status.

\section{No. 10}

A sleeveband

Silk satin, embroidery

Length: $69 \mathrm{~cm}$

Late $19^{\text {th }}$ century

Inv. No. 19363

Publication: Heroldová 2017, p. 70.

The sleeveband shows the auspicious motif of 'One Hundred Sons' (bai zi 百子). The motif of children playing is frequent in Chinese art and handicrafts. It symbolises an abundance, many male offspring, prosperity, and a family's advance in the social rank. ${ }^{41}$ Children are holding various auspicious objects: the vase with three halberds, which symbolised the desire for official promotion, ${ }^{42}$ coins (wealth), hat (official rank), and mushrooms for immortality.

\section{Gardens Scenes}

Besides the landscapes and flowers, the figural scenes are the most common sleeveband motifs found in the collection of the Náprstek Museum, although figural motifs, in general, are less frequent in Qing dress decoration. ${ }^{43}$ Garden scenes on the sleevebands pictured happy private lives of wealthy families. ${ }^{44}$ Women are strolling among the plants and around water ponds with flowers and fans in their hands, while children are running around and playing, men in informal gowns are enjoying their leisure time writing cal-

37 Heroldová 2017, p. 88.

38 Sleeveband with vases, probably a Manchu jacket, Haig and Shelton 2006, p. 137.

39 Welch 2008, p. 247.

40 Welch 2008, pp. 258-259.

41 Welch 2008, p. 157.

42 Welch 2008, p. 253

43 Wilson 1986, p. 61.

44 Garrett 2020, p. 194. 
ligraphy and painting pictures in garden pavilions, and couples are playing musical instruments; birds and butterflies are flying around, and flowers are in full bloom. Gardens in Chinese architecture embodied a secluded space within the house. Garden scenes appeared in Chinese genre paintings as a background for the depiction of festivals and family occasions, ${ }^{45}$ and in classical Chinese novels, they represented a space for family life. ${ }^{46}$

No. 11

A sleeveband

Silk satin, embroidery

Length: $100 \mathrm{~cm}$

Acquisition: Růžena Trnožková (1868-1936), 1937

Late $19^{\text {th }}$ century

Inv. No. A/5513

The long band can be folded in the middle so two similar embroidered decorations can be seen from both sides of the sleeve. On each side, there are four scenes with garden architecture, water at the bottom and mountains in the clouds at the top. Although the garden scene seems simple, it represents a complex symbolic meaning: the man is holding a vase with halberds that symbolize the advance in official rank.

\section{Repetitive Composition}

Densely laid motifs of flowers and fantastic butterflies are typical for the so-called Beijing style embroidery. ${ }^{47}$ The dense decoration of flowers gives an almost abstract impression.

\section{No. 12}

A sleeveband

Silk satin, embroidery

Length: $70 \mathrm{~cm}$

Acquisition: Rudolf Dvořák (1860-1920), 1961

Late $19^{\text {th }}$ century

Inv. No. A/1800

Contrasting colours enhanced the abstract effect of the repetitive pattern. This embroidery is in shades of blue with details in contrasting red.

\section{Sleevebands: Aesthetic and Symbolic}

The sleevebands were mostly embroidered on a light-coloured background, while the jackets were in dark colours - blue, purple, violet, or red. The striking visual contrast suggested the aesthetic function of sleevebands; ${ }^{48}$ however, the embroidered motifs of flowers, birds, and animals expressed also complex symbolic meanings. The Buddhist and Daoist motifs, auspicious objects along with the symbols based upon the world of Nature and traditional Chinese art and literature created an intricate 'vocabulary'

45 Cahill 2010, pp. 99-123.

46 Scott 1986, p. 83.

47 Haig and Shelton 2006, p. 141; Kuhn 2012, pp. 472-473.

48 Wilson 1986, p. 61. 
and combined these elements into an elaborated symbolic 'language'. Sleevebands, with their symbolism, hold not only the aesthetic function but also represented values appreciated by those who wore them as well as by those who saw them. Wearing garments with sleevebands and being surrounded by other women who wore them, too, enhanced the awareness of the life values of Qing dynasty women - wishes for long life, health, many male descendants, and an advance in career for members of the family.

\section{Literature:}

Bertholet, F. and van der Aalsvoort, L. (2014). Among the Celestials: China in Early Photographs. Brussels: Mercatorfonds.

Cahill, J. (2010). Pictures for Use and Pleasure: Vernacular Painting in High Qing China. Berkeley: University of California Press.

Cahill, J. (2013). Beauty Revealed. Images of Women in Qing Dynasty Chinese Painting; [is published in conjunction with the Exhibition Beauty Revealed: Images of Women in Qing Dynasty Chinese Painting, organized by the University of California, Berkeley Art Museum and Pacific Film Archive, and on view from September 25 to December 22, 2013]. Berkeley, CA: University of California, Berkeley Art Museum and Pacific Film Archive.

Chung, Y. (2006). Painting with a Needle: Learning the Art of Silk Embroidery. New York: Harry N. Abrams Inc.

Cody, J. and Terpak, F. (2011). Brush E Shutter: Early Photography in China. Los Angeles, CA: Getty Research Institute.

Crick, M. (2004). Sous la Griffe du Dragon: Costumes de Cour de la Dynastie Qing (16441911) des Collections Baur, Musée des Arts d'Extrême-Orient et du Musée d'Ethnographie de Genève; aux Collections Baur du 5 novembre 2004 au 20 février 2005. Genève: Collections Baur.

Fajcsák, G. and Kelényi, B. (2017). Sanghay = Shanghai: Parallel Diversities between East and West. Budapest: Ferenc Hopp Museum of Asiatic Arts.

Fong, G. (2004). Female Hands: Embroidery as a Knowledge Field in Women's Everyday Life in Late Imperial and Early Republican China. Late Imperial China, 25 (1), pp. 1-58.

Garrett, V. (2020). Chinese Dress: from the Qing Dynasty to the Present Day. S. L.: Tuttle Publishing.

Haig, P. and Shelton, M. (2006). Threads of Gold: Chinese Textiles: Ming to Ching. Atglen, PA: Schiffer.

Heroldová, H. (2011). The Exotic Salon of the Master of the House: The History of Václav Stejskal Collection. Praha: Národní muzeum.

Heroldová, H. (2013). Sober Luxury: Three Examples of Late Kesi Silk Tapestries in the Náprstek Museum. Annals of the Náprstek Museum, 34(2), pp. 19-29.

Heroldová, H. (2017). Between Cultures: Manchu and Han Dress of the Late Qing Dynasty in the Náprstek Museum Collection. Prague: Národní muzeum. 
Heroldová, H. and Mleziva, J. (2011). Činský textil ve sbírce Západočeského muzea v Plzni. Plzeň: Západočeské Muzeum.

Heroldová, H. and Todorovová, J. (2018). A Family Portrait: Enrique Stanko Vráz and the Qing Aristocracy During the Boxer Rebellion. Annals of the Náprstek Museum, 39(1), pp. 51-74.

Kuhn, D. and Zhao, F. (2012). Chinese Silks. New Haven, CT: Yale University Press.

Kuhn, D. (1995). Silk weaving in Ancient China: From Geometric Figures to Patterns of Pictorial Likeness. East Asian Science, Technology, and Medicine, 12(1), pp.77-114.

Liu Qiyu (1992). Zhongguo da baike quanshu. Beijing - Shanghai: Zhongguo da baike quanshu chubanshe.

Paine, S. (2010). Embroidered Textiles: a World Guide to Traditional Patterns. London: Thames \& Hudson.

Rawson, J. (2006). Ornament as System: Chinese Bird-and-Flower Design. The Burlington Magazine, 148 (1239), pp. 380-389.

Scott, M. (1986). The Image of the Garden in Jin Ping Mei and Hongloumeng. Chinese Literature: Essays, Articles, Reviews (CLEAR), 8(1/2), p. 83-94.

Welch, P. (2008). Chinese Art: a Guide to Motifs and Visual Imagery. North Clarendon, VT: Tuttle Pub.

Welters, L. and Lillethun, A. (2018). Fashion History: a Global View. London - New York: Bloomsbury Academic.

Wilson, V. (1986). Chinese Dress. Bamboo Publishing LTD with the Victoria and Albert Museum.

Yeh, C. (2006). Shanghai love: Courtesans, Intellectuals, and Entertainment Culture, 18501910. Seattle: University of Washington Press.

Zhou, X. and Gao, Ch. (1997). Zhongguo Lishi Fushi. Shanghai: Xuelin chubanshe.

Zurndorfer, H. (1999). Chinese Women in the Imperial Past: New Perspectives. Leiden Boston, MA: Brill.

Complete Textile Glossary (2001). New York, NY: Celanese Acetate. 
Pl. 1

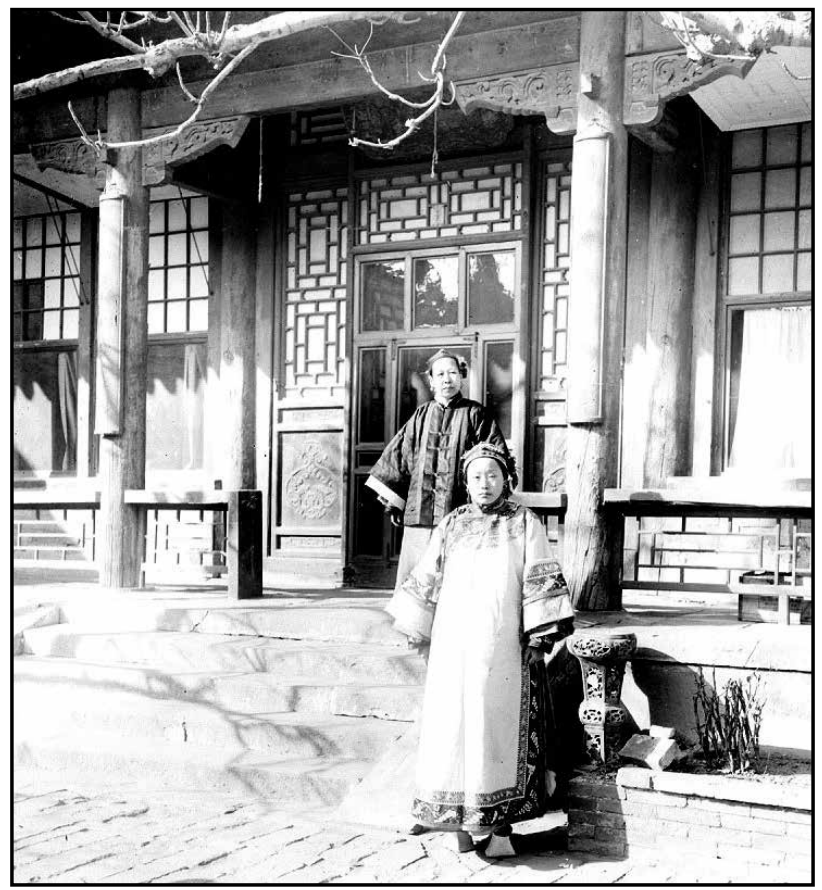

No. 1

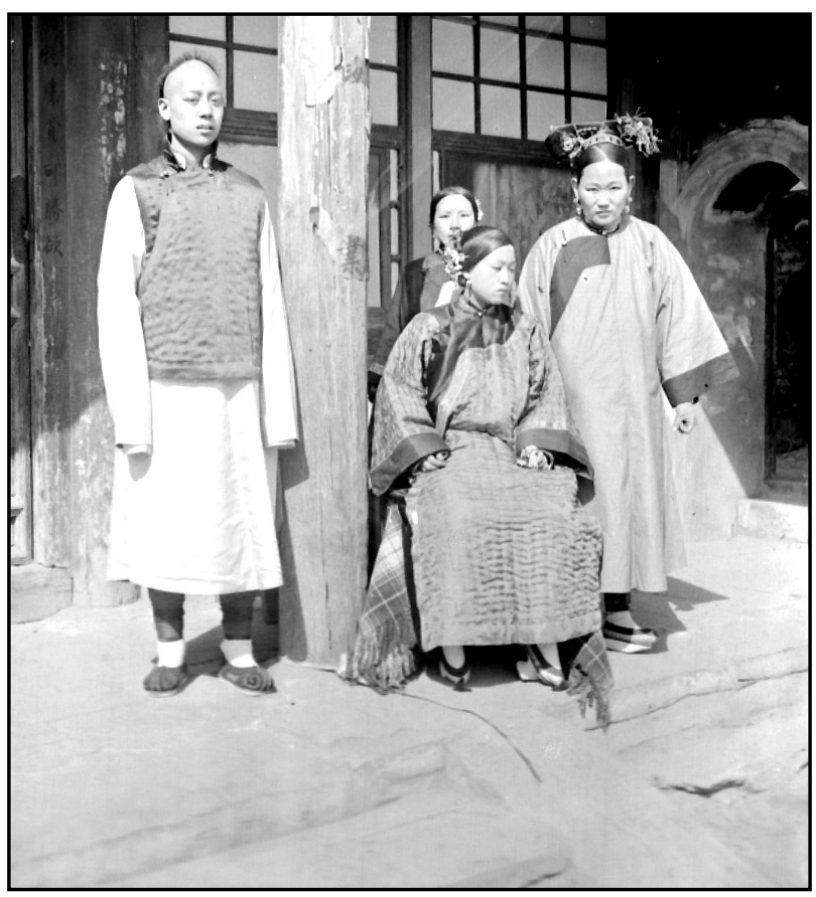

No. 2 
P1. 2

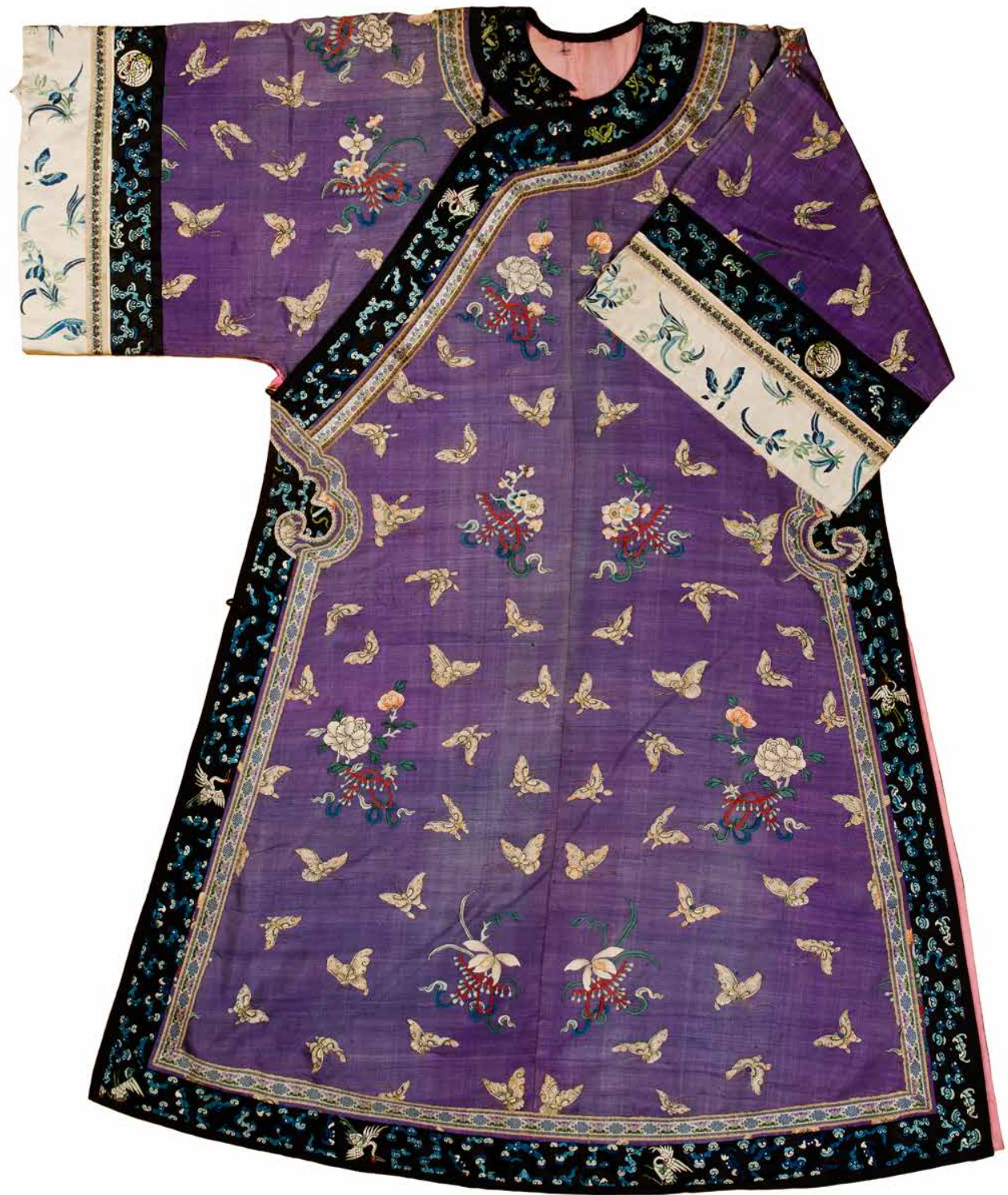

No. 3 
Pl. 3

C. -

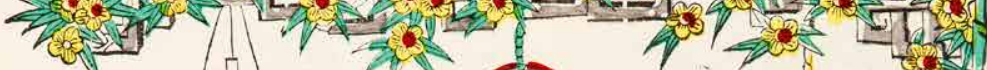
sas

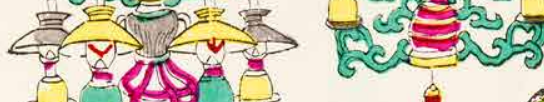
|riाlil"
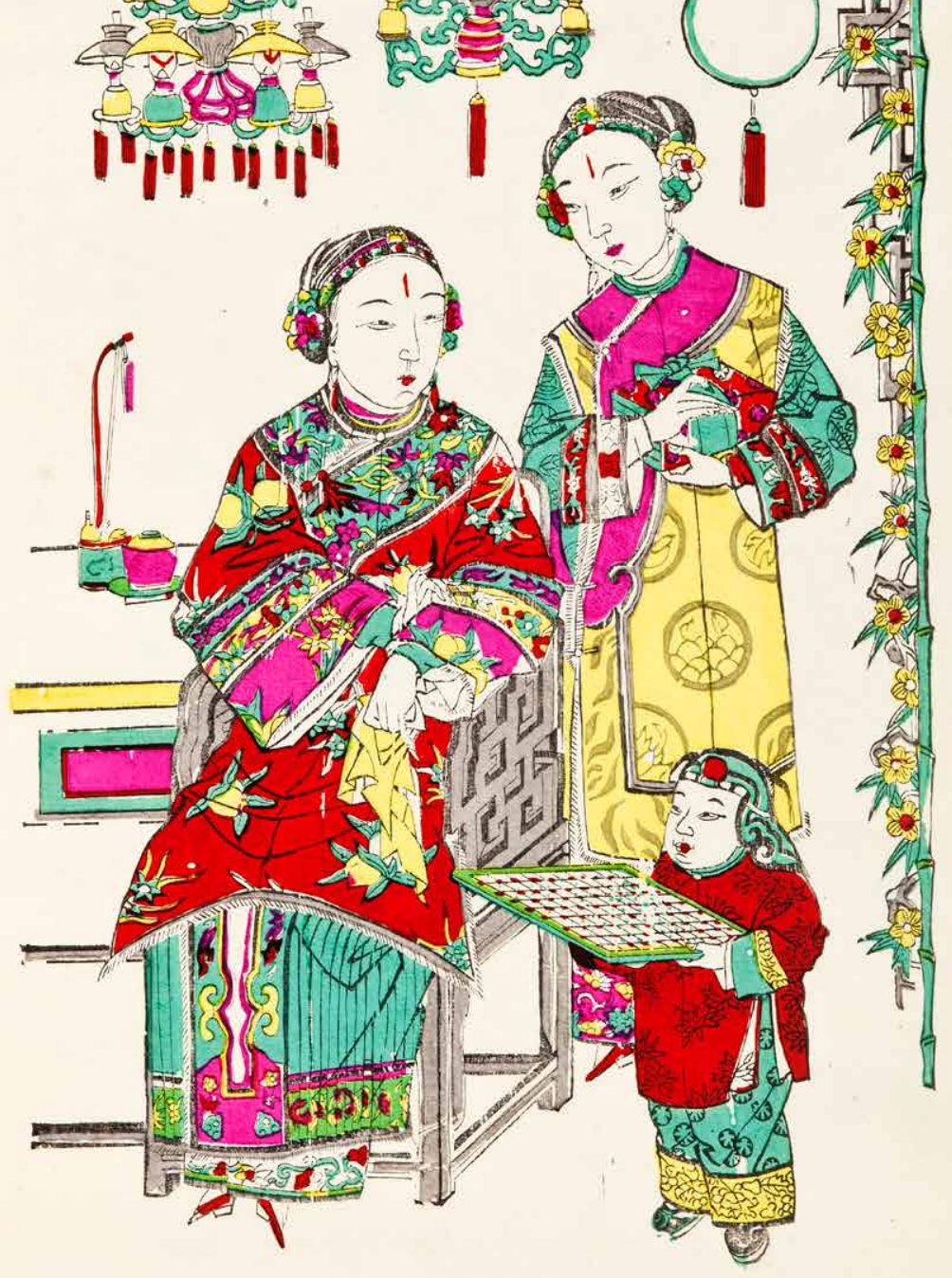

No. 4 
P1. 4

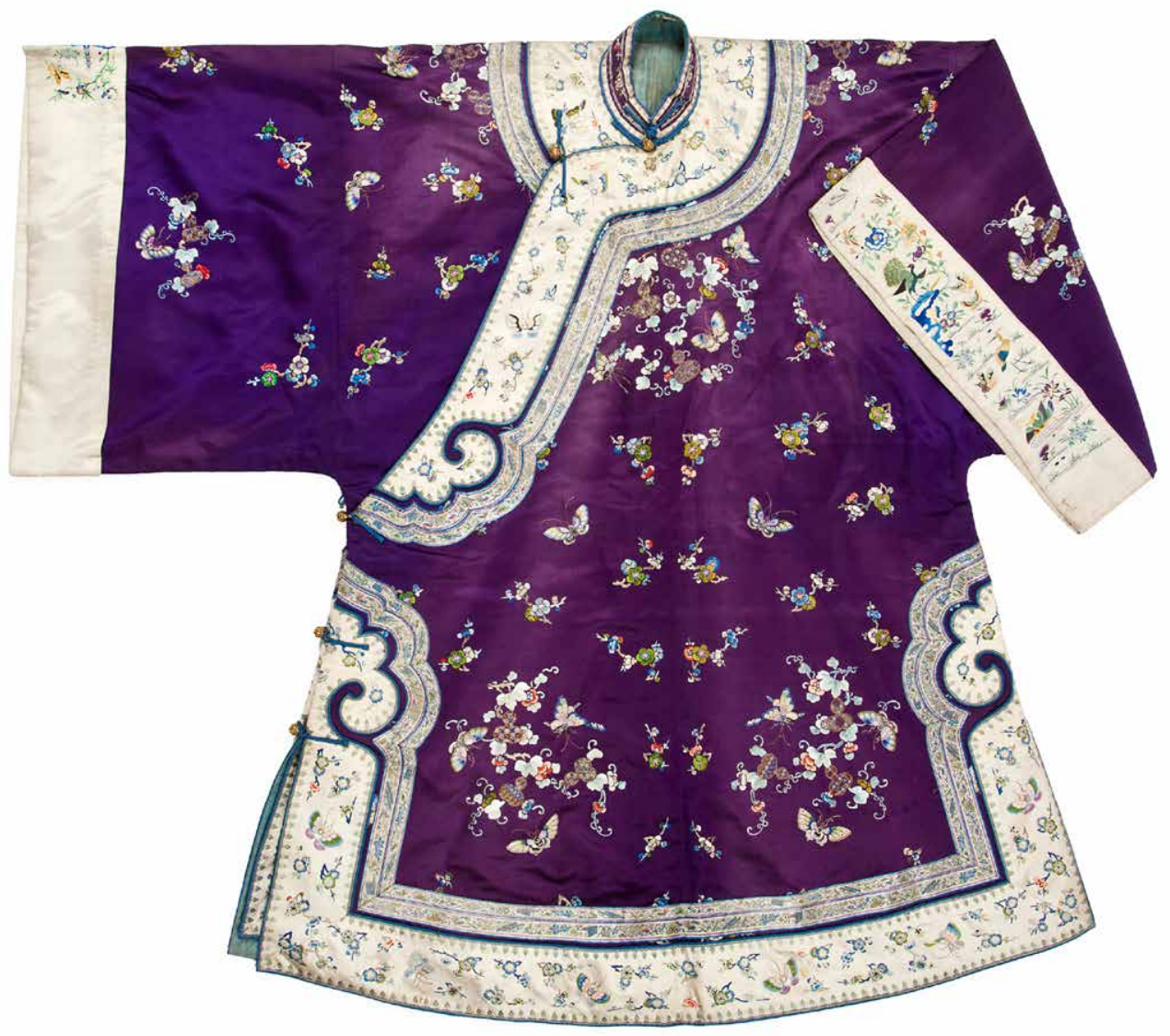

No. 5 
Pl. 5
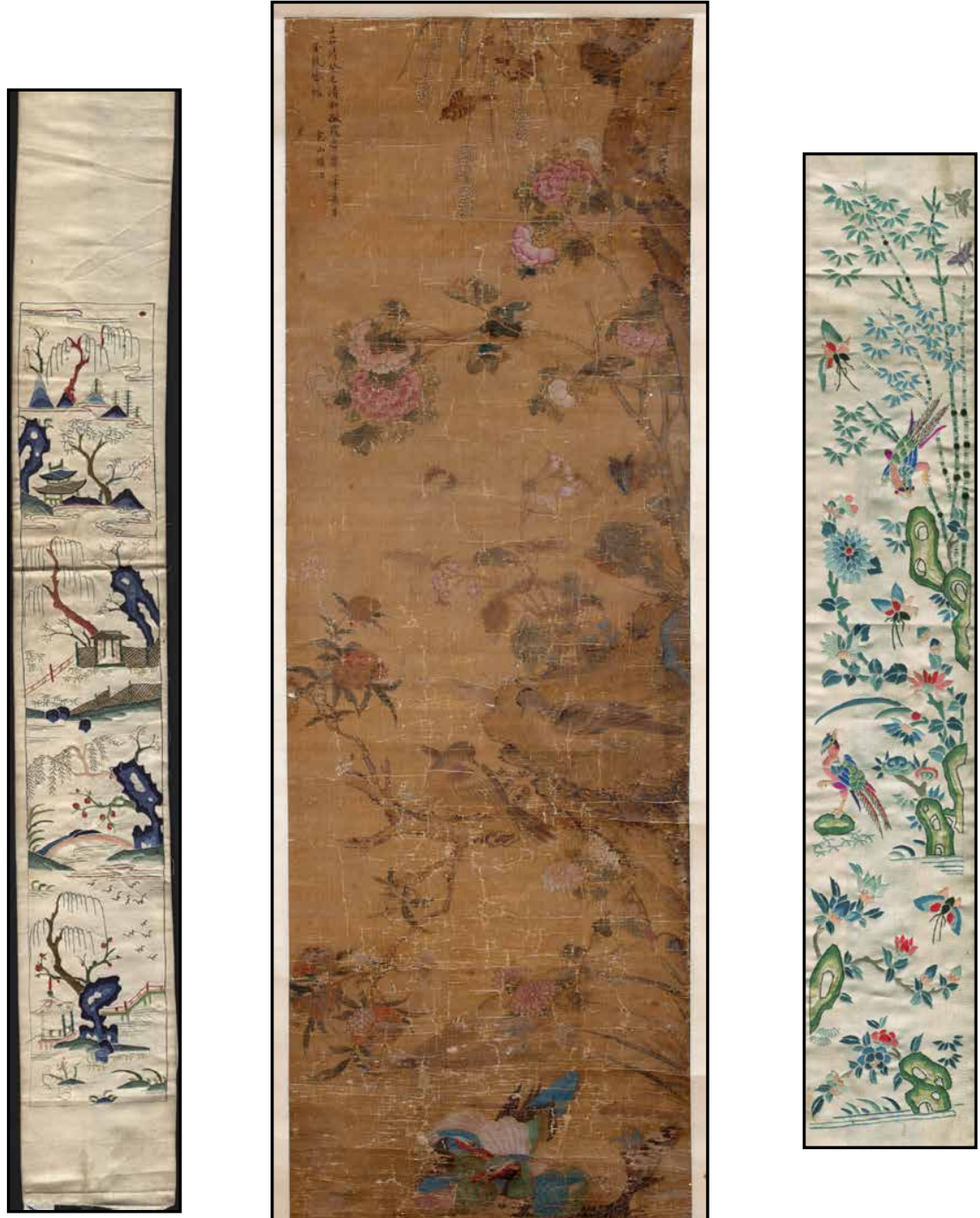

No. 6

No. 7

No. 8 

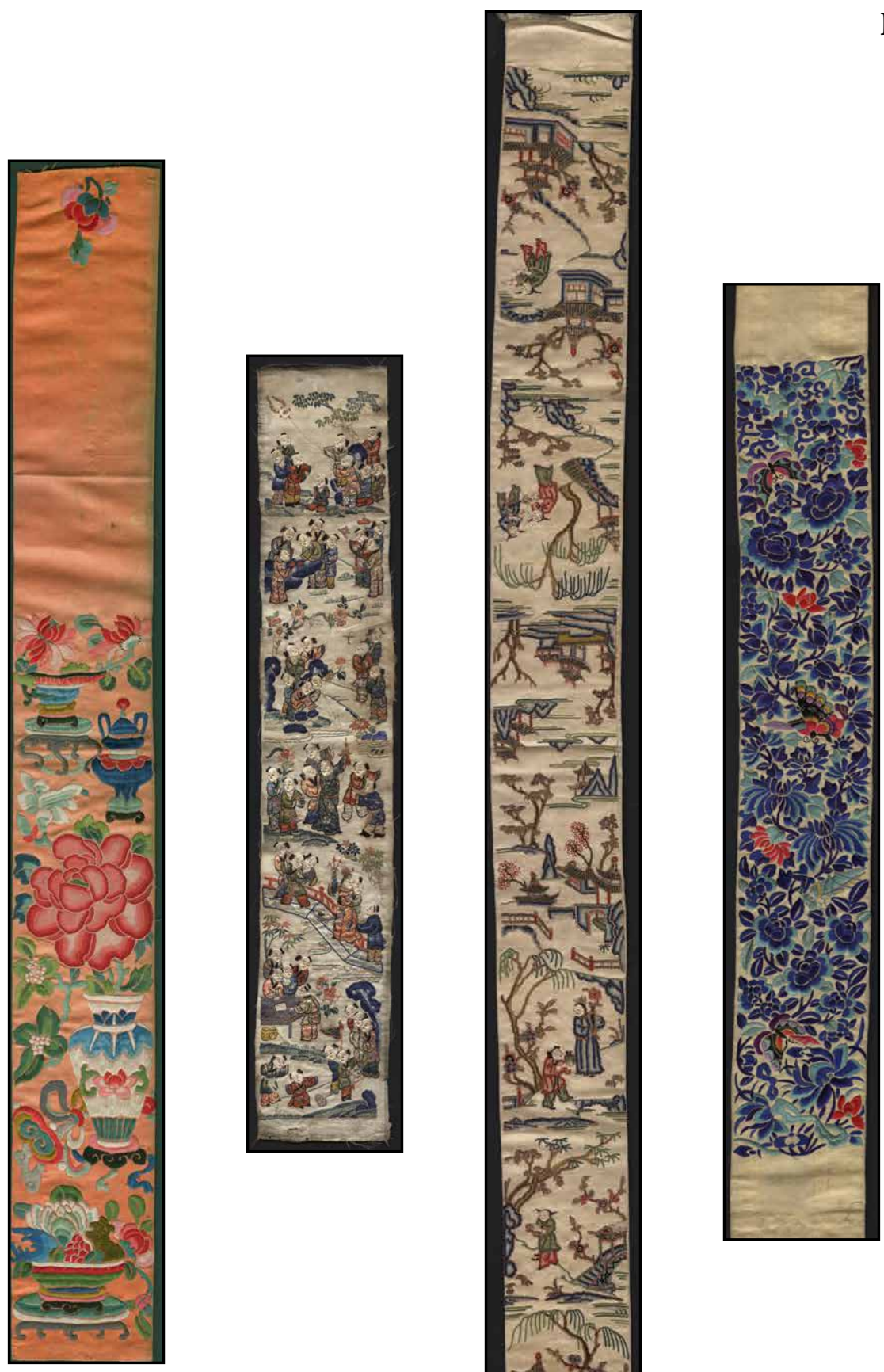

Pl. 6

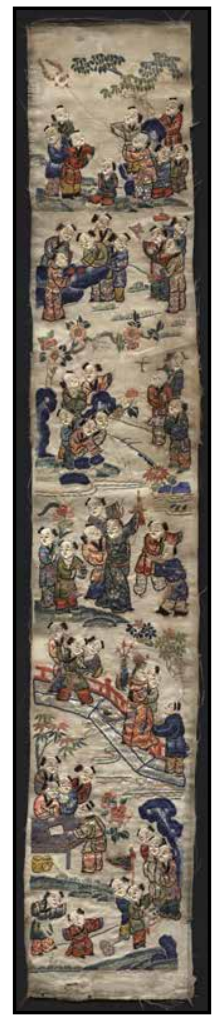

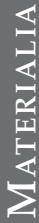

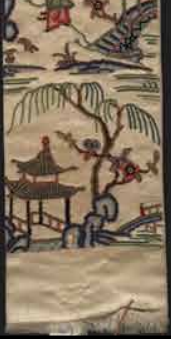

No. 11

No. 12 